\title{
Addressing Nuclear Challenges, Misperceptions and Geopolitics in South Asia
}

\author{
Author: Chaudhry, Aizaz Ahmad
}

To cite this article: Chaudhry, A. A. (2022). Addressing Nuclear Challenges, Misperceptions and Geopolitics in South Asia. National Security Journal. Published 27 February 2022. doi:10.36878/nsj20220227.09

To link to this article: https://doi.org/10.36878/nsj20220227.09

View CrossRef data: https://search.crossref.org/?q=10.36878\%2Fnsj20220227.09 


\title{
ADDRESSING NUCLEAR CHALLENGES, MISPERCEPTIONS AND GEOPOLITICS IN SOUTH ASIA
}

\author{
Aizaz Ahmad Chaudhry ${ }^{1}$
}

\begin{abstract}
India and Pakistan, two nuclear-armed neighbours, have vital stakes in maintaining strategic stability in South Asia. However, some disturbing shifts are now being observed in India's approach towards the imperatives of strategic stability. Its aggressive pursuit of military modernisation and acquisition of emerging technologies, coupled with reported doctrinal shifts, such as pre-emptive counterforce strategy, pose a serious challenge to nuclear deterrence. The Indian leadership seems to have been emboldened by the US tilt towards India, manifested by the growing US-India strategic partnership. These developments have heightened $\mathrm{Pa}$ kistan's sense of insecurity. This essay seeks to assess the short-, medium- and long-term challenges to strategic stability in South Asia. It suggests a three-tiered framework of confidence-building measures at the bilateral level between India and Pakistan, the trilateral level among China, India and Pakistan, and the multilateral level whereby the major powers could facilitate conventional and nuclear confidence-building measures in the region.
\end{abstract}

Key Words: South Asia, strategic stability, nuclear deterrence, confidence-building measures

\section{Introduction}

Ever since the nuclearisation of South Asia in 1974, when India conducted its first nuclear weapons test, the cause of peace has been best served only when strategic stability has been maintained in the region. ${ }^{1}$ While there is no agreed definition of strategic stability, it commonly refers to either the absence of incentives to use nuclear weapons first

1 Ambassador Aizaz Ahmad Chaudhry served as a member of the Foreign Service of Pakistan for 37 years, rising to the rank of the Foreign Secretary of Pakistan from December 2013 to March 2017. He has served as Ambassador of Pakistan to the United States and the Netherlands, Foreign Office Spokesman and deputy permanent representative of Pakistan to the United Nations. 
under crisis stability or incentives to build up a nuclear force under arms race stability. This definition can further be expanded to refer to the absence of armed conflict between nuclear-armed states and even more broadly to a regional security environment in which states have peaceful relations. Irrespective of its formulation, there have been developments that complicate strategic stability in South Asia.

Pakistan has sought to maintain strategic stability, even as India has sought to tilt this balance in its favour. India's offensive nuclear force posture coupled with doctrinal shifts and aggressive conventional undertakings have accentuated conventional asymmetries, challenging nuclear deterrence and strategic stability in South Asia. ${ }^{2}$ These activities have been enabled by the active support of the United States and other partners in the West, which have opened the technological spigots and relaxed their strategic export controls to build India as a counterweight to China. This US investment in India is exacerbating Pakistan's security dilemma and increasing strategic instability. ${ }^{3}$ This essay will explore these various factors to address near-, mid- and long-term challenges, misperceptions and geopolitical factors to identify recommendations for fostering strategic stability in South Asia.

\section{Near-, Medium- and Long-Term Challenges}

South Asia is beset by a range of challenges that weaken strategic stability in the region. Near-term challenges emanate from India's newfound tendency to conduct surgical strikes against Pakistan. Medium-term risks stem from the reports of India's shift towards pre-emption in conventional and nuclear domains portending a high risk of miscalculation. Long-term concerns about strategic stability in South Asia come from growing Indian ambitions to assert its hegemony in South Asia, marked by its concomitant efforts to coerce and dominate its smaller neighbours.

\section{Near-Term Challenges}

In the near term, a major risk stems from India's strategy of surgical strikes against Pakistan, which is predicated upon the assumption that the two nuclear-armed states can engage in the limited conventional confrontation while staying below the nuclear threshold. However, such a concept is fraught with the risk of nuclear escalation. In September 2016, India claimed to have carried out a surgical strike against targets across the line of control (LOC) even though the strike did not actually take place. ${ }^{4}$ Then, in February 2019, India carried out a stand-off bombing near the Balakot area of the Khyber Pakhtunkhwa province of Pakistan and claimed to have killed 300 persons. ${ }^{5}$ This time, the strike was carried out, but no one was killed. ${ }^{6}$ India perhaps wanted to establish a 'new normal' of conducting surgical strikes against Pakistan at will, presuming that Pakistan's response would remain conventional and would not escalate to a nuclear exchange. Within this, external actors-primarily the United States and its allies in the 
West-initially encouraged India to escalate and blamed Pakistan, only seeking to defuse the situation later following Pakistan's restrained and proportional response. ${ }^{7}$

Critically, India's strategy of conducting surgical strikes is highly irresponsible since even minor conventional conflict has the potential to escalate into a nuclear exchange between the two with unthinkable consequences. Further, this high-risk approach is an upgrade of India's cold start doctrine, which aimed to find space for a limited conventional war under Pakistan's nuclear threshold. ${ }^{8}$ For years, India denied having adopted this doctrine until its military leaders acknowledged its existence. ${ }^{9}$

This upgrade from cold start to pre-emptive surgical strikes has been further complicated by India's conduct of terrorism inside Pakistan, which seeks to wage hybrid warfare below the kinetic threshold. In November 2020, Pakistan presented evidence of Indian sponsorship of terrorism in Pakistan during a press conference in which Foreign Minister Shah Mahmood Qureshi made public a dossier of Indian financial and material sponsorship of multiple terrorist organisations, including United Nations (UN)-designated terrorist organisations Jamaat-ul-Ahrar, Balochistan Liberation Army and Tehreek-i-Taliban Pakistan, and stated 'today we presented irrefutable evidence to the world on Indian state's insatiable appetite for terrorism, violence and instability, funding banned organisations, arming terrorists, savage attacks on innocent civilians and desperately trying to lobby against Flag of Pakistan's growing global role of peace and progress; India has become a rogue state. It is time the world wakes up to an Indian state that is only incredible in its fanaticism. ${ }^{10}$

Foreign Minister Qureshi also referred to terrorist attacks, in particular incidents in Quetta and Peshawar, which were a manifestation of India's 'grand design' to destabilise Pakistan, disrupt its journey towards economic revival, cause political upheaval and sabotage the China-Pakistan Economic Corridor (CPEC).$^{11}$ In September 2021, Foreign Minister Qureshi presented another more detailed dossier on India’s war crimes and human rights violations in Indian-occupied Kashmir. ${ }^{12}$ The dossier comprised three chapters: the first on war crimes by the Indian army and its genocidal actions; the second on the disappointment of Kashmiris and how a local resistance movement is being established despite the propaganda of normality; and a third on how UN Security Council (UNSC) resolutions, international laws and humanitarian laws are being violated through efforts to bring about demographic change in the valley. The majority of the references in the dossier came from international and Indian media outlets as well as international human rights organisations.

\section{Medium-Term Challenges}

In the medium term, a serious challenge to strategic stability in South Asia is marked by India's reported shift in nuclear posture towards a pre-emptive counterforce strategy, under which it would seek to achieve escalation dominance by completely dis- 
arming Pakistan of its nuclear weapons. ${ }^{13}$ If implemented, this strategy would precipitate increased nuclear force alert and readiness status on both sides. Not only would a pre-emptive counterforce strategy mean that India would increase the readiness of its nuclear forces, but Pakistan would also have to revise its nuclear force posture since it may be faced with a use-it-or-lose-it dilemma. When faced with an imminent nuclear attack from India, Pakistan would have to decide whether to wait and risk losing the majority of its nuclear arsenal or to launch a nuclear attack. This would be highly destabilising. As a result, there would be a significant compression of time in avoiding a miscalculation that could result in a nuclear exchange between India and Pakistan.

This potential shift towards counterforce is occurring in the wake of statements by Indian leaders, such as India's Defence Minister Rajnath Singh's statement on India's no-first-use (NFU) policy on August 16, 2019, which stated that India's NFU policy had been adhered to thus far, but 'what happens in the future depends on the circumstances. ${ }^{14}$ Further, in 2016, India's Defence Minister Manohar Parrikar stated 'Why do lot of people say that India is for "not first use... why should I bind myself? I should say I am a responsible nuclear power and I will not use it irresponsibly. ${ }^{15}$ Such statements have sown doubts over India's commitment to its stated posture of NFU. This has further contributed to some experts concluding that India has been moving towards a pre-emptive counterforce strategy. ${ }^{16}$ While India may have undertaken an NFU pledge, ${ }^{17}$ its abandonment of minimal credible deterrence in favour of a rapidly growing strategic nuclear triad and military space programme suggests otherwise. ${ }^{18}$

\section{Long-Term Challenges}

In the long term, Indiass hegemonic ambitions for South Asia, which tries to coerce and dominate its smaller neighbours, demonstrates an unwillingness to resolve deeprooted nuclear flash point disputes like Kashmir, and undertakes a confrontational approach towards its neighbours has contributed to perpetual instability in South Asia. These include India's actions of August 2019 whereby it stripped Kashmiris of the special autonomy they had for seven decades through a rushed presidential order and by repealing Article 370 of the Indian constitution. ${ }^{19}$ India's move to unilaterally annex the disputed territory of Jammu and Kashmir is a violation of UNSC resolutions, which prohibit any unilateral change to the disputed status of the territory until Kashmiris are granted their right to self-determination through an UN-sponsored plebiscite. ${ }^{20}$

Along with this presidential order came the excessive and brutal use of force by Indian security forces against the people of Jammu and Kashmir. ${ }^{21}$ There has been a worldwide protest over the gross human rights violations perpetrated against Kashmiris. These actions also violate the bilateral Simla Agreement of 1972, whereby both India and Pakistan committed not to 'unilaterally alter the situation. ${ }^{22}$ Of late, India is also carrying out demographic engineering in the occupied Kashmir with the aim of changing its Muslim majority status. ${ }^{23}$ 


\section{Misperceptions on Strategic Stability in South Asia}

In addition to the aforementioned challenges, there are a number of misperceptions on strategic stability in South Asia that must be addressed. These misperceptions arise out of a lack of effective platforms for bilateral communication and dialogue, provocative and irresponsible rhetoric, as well as deliberate attempts to build negative narratives about the adversary.

\section{India}

The first among the misperceptions regarding India is the view that it is a responsible nuclear state and is engaged in moderate military modernisation. ${ }^{24}$ India's nuclear weapons complex is expanding rapidly, with concomitant increases in its fissile material stockpiles. India has estimated 5.2 \pm 1.6 tonnes of highly enriched uranium (HEU) enriched to about 30 per cent uranium-235, $0.6 \pm 0.15$ tonnes of weapon-grade plutonium, and 8.2 \pm 3.5 tonnes of reactor-grade plutonium that includes 0.4 tonnes of safeguarded plutonium. ${ }^{25}$ It is also pursuing a sustained military build-up, which has severe implications for regional peace and security. Its defence spending was $\$ 64.1$ billion in 2020, only second to China in the region. ${ }^{26}$ Further, the military trade between the US and India alone has reached approximately $\$ 20$ billion in the last 15 years, and India has also been buying defence equipment from Russia and Israel. ${ }^{27}$

The second among the misperceptions is that India's political and military leadership has been restrained in its statements and actions. India's leaders have been engaged in provocative rhetoric and war mongering, which have reached dangerously high levels, including Parrikar's 2016 statement on NFU cited above. In October 2017, the Indian Air Force Chief Marshal, B.S. Dhanoa, stated that "the Indian Air Force (IAF) can target Pakistan's nuclear sites and has the capability to help the army in carrying out surgical operations. ${ }^{28}$ India's Chief of the Army Staff, General Bipin Rawat, has also repeatedly threatened Pakistan with a surgical strike, as with his September 2017 threat to repeat Indian surgical strikes against Pakistan. ${ }^{29}$ A related dimension is India's tendency to justify its official rhetoric and acts of aggression against Pakistan under the garb of fighting terrorism. ${ }^{30}$

\section{Pakistan}

The first among the misperceptions pertaining to Pakistan is the view that Pakistan's nuclear programme is the fastest growing. ${ }^{31}$ This is mere speculation and not based on the facts that instead suggest that estimates around Pakistan's nuclear arsenal lack primary source data. ${ }^{32}$ Nuclear deterrence is not a static concept. India's pursuit of advanced missiles, precision-strike weaponry, a layered ballistic missile defence system and second-strike capability necessitates qualitative and quantitative changes to Pakistan's nuclear forces in order to maintain the credibility of nuclear deterrence. ${ }^{33}$ 
The second misperception is that Pakistan's nuclear assets could land in the hands of the terrorists. This potential has been disproven by Pakistan's record on the safety and security of its nuclear programme. ${ }^{34}$ Furthermore, over the past two decades, Pakistan has confronted terrorism at a great human and financial sacrifice, and has succeeded in this endeavour. ${ }^{35}$ At no point in time have Pakistan's nuclear assets come under any threat of theft or misappropriation. ${ }^{36}$ This is because Pakistan has invested in creating a robust command and control system. ${ }^{37}$ Further, Pakistan has instituted an additional layer of export controls so that no item of dual-use technology enters or leaves the country without scrutiny ${ }^{38}$ Pakistan has also engaged in comprehensive nuclear security cooperation with International Atomic Energy Agency (IAEA) and participated actively in the four Nuclear Security Summits from 2010 to $2016 .{ }^{39}$

The third misperception is that Pakistan would share its nuclear technology with Muslim countries or other states. Pakistan has invested more than any other state in ensuring that its nuclear technology remains secure and strictly used for its defence and peaceful use in agriculture, medicine and industry. ${ }^{40}$ Nonetheless, a series of myths have resulted suggesting that since Pakistan is a Muslim state and a nuclear weapon developed by it would be shared with other countries and terms it as an 'Islamic bomb. ${ }^{\text {.1 }}$ As just one example of such mischaracterisations, in November 2013 a media report emerged that Pakistan's nuclear weapons would be shared with Saudi Arabia. ${ }^{42}$ Pakistan immediately discredited this story as it has always maintained that its nuclear assets are only for the defence of Pakistan and to deter any aggression against it. ${ }^{43}$

\section{Geopolitics Shaping Nuclear South Asia}

The above misperceptions about India's and Pakistan's nuclear programmes are propagated mostly by Western media as a pressure tactic against Pakistan in the context of South Asian geopolitics. Further, the international community has tended to overlook its own collective peril in India's massive militarisation coupled with the irresponsible rhetoric of its leaders. Instead, it has encouraged India's activities by signing deals and long-term defence agreements. ${ }^{44}$ To better understand the impact of these misperceptions on strategic stability, it is crucial to examine the geopolitics impacting South Asia.

\section{United States}

At one level, the situation in South Asia may be viewed in the context of evolving US-China strategic competition, which appears to be intensifying. The US Indo-Pacific strategy and its forerunner the US pivot and rebalance to the Asia-Pacific region were aimed at counter-balancing a rising China. ${ }^{45}$ The United States has chosen India as its key ally in this endeavour. ${ }^{46}$ As a result, the US-India strategic partnership is emerging as a major threat to the strategic balance in the South Asian region. The United States has facilitated exceptions and special waivers for India at the IAEA and the Nuclear Suppliers Group as part of these efforts. 
The United States has also signed defence agreements with India and is supplying military hardware worth billions of dollars. Among these, it has concluded with India the Defence Trade and Technology Initiative in 2012, the Logistics Exchange Memorandum of Agreement in 2016, the Communications, Compatibility and Security Agreement in 2018 and the Basic Exchange and Cooperation Agreement in 2020. ${ }^{47}$ Furthermore, India has signed civil nuclear deals with the United States among others, thus sparing its own fissile material for military purposes. ${ }^{48}$ India has also teamed up with the United States, Australia and Japan in the Quadrilateral Security Dialogue, purportedly to watch over the sea lanes of communications and contain China. ${ }^{49}$

Notably, the US strategic tilt has emboldened India's present leadership to embark on an ambitious project of internally creating a Hindu 'Rashtra' or nation, while externally establishing South Asia as its exclusive area of influence. ${ }^{50}$ The creation of Hindu Rashtra is ostensibly aimed at reviving Hindu glory. The project is propelled by the philosophy of Rashtriya Swayamsevak Sangh (RSS), which envisions no space for non-Hindus and is especially hostile towards the Muslims of India. ${ }^{51}$ India is now going through an internal convulsion pushing the country farther away from its avowed principles of democracy, secularism and pluralism that its founding fathers espoused.

Externally, India is now engaged in a confrontational mode with most of its neighbours, also enabled by the United States. With Pakistan, India has been trying to seek a military solution for the past several decades to a simmering dispute over Jammu and Kashmir. ${ }^{52}$ The continual skirmishes at the LOC have consistently jeopardised the peace and tranquillity of the region..$^{53}$ India's heavy-handed approach towards Nepal and Sri Lanka and its recent stand-off with China in Ladakh have further contributed to the instability in South Asia. ${ }^{54}$ Further, India's use of Afghanistan to create terrorism and instability in Pakistan seems to be a part of its strategy of pressurising Pakistan from both east and west, often referred to as the 'double squeeze' against Pakistan. ${ }^{55}$ These activities, which are enabled through US support, suggest the need for it to play a greater role in advising India to change its present confrontational approach and to work towards regional peace.

\section{China and Russia}

As it relates to South Asia, China appears to be desirous of a peaceful rise and stability in its bordering regions. China has consistently supported multilateralism and globalism, as reflected in the connectivity and infrastructure development under its Belt and Road Initiative (BRI) which has engaged and benefited over sixty countries. ${ }^{56}$ China has also embarked on six economic corridors, including one involving Pakistan, called CPEC. Regrettably, India has chosen to oppose both BRI and CPEC..$^{57}$ The combined US and Indian opposition to the BRI creates tensions with China and contributes to tensions in the region. 
Alongside China's economic engagement of the region, Russia stands as one of India's oldest and largest military hardware suppliers. ${ }^{58}$ As of 2018, India and Russia signed an agreement for the sale of the S-400 air defence system, which could further destabilise the region building further pressure on strategic stability. In 2020, Russia also offered three refurbished Kilo-class submarines to India, which could also exacerbate regional tensions and a potential naval arms race. Further, India has commenced manufacturing 400 T-90S battle tanks, extending their building license through $2028 .{ }^{59}$ While these defence deals have a destabilising impact on strategic stability, there are examples of growing synergies between Pakistan and Russia that could be stabilising, such as their cooperation in building a North-South gas pipeline in Pakistan.

\section{Conclusion}

In confronting the challenges, misperceptions and geopolitics that threaten strategic stability in South Asia, a three-tiered framework of confidence-building measures is required. Bilaterally, Pakistan proposed in 2006 a three-pronged Strategic Restraint Regime to India, comprising nuclear restraint, conventional balance and conflict resolution. ${ }^{60}$ Unfortunately, this proposal was neither accepted nor responded to by India. Yet, in the larger interest of peace, the region does need a mutually acceptable restraint regime that enables India and Pakistan to engage in discussions on conflict prevention and nuclear risk reduction. Trilaterally, China, India and Pakistan should engage in trilateral dialogues at the track-2 level, and later track-1.5 level. Among the topics that would be eligible for discussion are prevention of nuclear related accidents, confidence building measures, and regular platform for trilateral dialogue. These dialogues would enhance mutual understanding among these three countries and contribute to strategic stability in South Asia.

Multilaterally, the United States, China and Russia could facilitate a revival of the India-Pakistan expert group meetings on conventional and nuclear CBMs that operated from 2004-2012, producing many useful nuclear confidence-building measures and agreements. Given India's sensitivities about external involvement in the region, this could be accomplished through informal dialogue either at the UN General Assembly's First Committee meetings or on the side lines of the Conference on Disarmament in Geneva. Further, regional economic integration and connectivity, as under the rubric of the Shanghai Cooperation Organisation, in which both India and Pakistan are members, could also be fostered to assist in building mutual confidence in the South Asian region. At a time when major power competition, primarily between the United States and China, seems to be intensifying, it is important that India and Pakistan do not get caught up in this competition. Instead, it is crucial for the two sides to undertake measures at the bilateral, trilateral and multilateral levels, to reduce nuclear related risks and bolster mutual confidence about each other's intent and capabilities in the larger interest of strategic stability in South Asia. 
1 Comprehensive Nuclear-Test-Ban Treaty Organization, '18 May 1974 - Smiling Buddah', $<$ https:// www.ctbto.org/specials/testing-times/18-may-1974-smiling-buddah>, accessed on 12 Oct. 2021; and Acton, James, 'Reclaiming Strategic Stability', 5 Feb. 2013, <https://carnegieendowment.org/2013/02/05/ reclaiming-strategic-stability-pub-51032>.

2 Nuclear deterrence prevents two nuclear armed adversaries from launching an attack on the other out of fear of a counter nuclear attack with unacceptable damage. Each nuclear power maintains a high level of instant and overwhelming destructive capability against any aggression - the ability, visible and credible to a would-be attacker, to inflict unacceptable damage upon the attacker with forces that survive a surprise attack.

3 The theory of security dilemma was originated by John Herz. He argued that in an anarchic international system, states are concerned about their security. An increase in power by one state threatens other states, causing them to acquire power. This renders state insecure thus resulting in action-reaction spiral of power and security accumulation. Herz, John, 'Idealist Internationalism and the Security Dilemma', World Politics, vol. 2, no. 2, January 1950, pp. 157-180, <https://www.cambridge.org/core/ journals/world-politics/article/abs/idealist-internationalism-and-the-security-dilemma/7094783665386FD81A25DF98C7EEC223>. Security is viewed as a zero-sum game, resulting in greater instability as the opponent responds to the resulting reductions in security. Barry Buzan calls this security dilemma a 'power-security dilemma'. Buzan, Barry, People, States and Fear: The National Security Problem in International Relations (Chapel Hill, N.C.: University of North Carolina Press, 1983), p. 157.

4 Abbas, Syed Sammer, ‘Army rubbishes Indian 'surgical strikes' claim as two Pakistani soldiers killed at LoC', Dawn, 29 Sep. 2016, <https://www.dawn.com/news/1286881>.

5 Economic Times, 'Indian air strike in Balakot killed 300 militants: Sources', 26 Feb. 2019, <https:// economictimes.indiatimes.com/news/defence/indian-air-strike-in-balakot-killed-300-militants-sources/ articleshow/68165466.cms $>$.

6 Iqbal, Anwar, 'Experts question India's claim of destroying militant camp near LoC', Dawn, 27 Feb. 2019, <https:/www.dawn.com/news/1466258/experts-question-indias-claim-of-destroying-militantcamp-near-loc >.

7 Dawn, '2 Indian aircraft violating Pakistani airspace shot down; pilot captured', 27 Feb. 2019, $<$ https://www.dawn.com/news/1466347>; and Dawn, 'Pakistan frees captured Indian pilot Abhinandan in peace gesture," 1 Mar. 2019, <https://www.dawn.com/news/1466951>.

8 Ladwig III, Walter C., 'A Cold Start for Hot Wars? The Indian Army's New Limited War Doctrine', Quarterly Journal: International Security, vol. 32. no. 3. (Winter 2007/08): 158-190, <https://www. belfercenter.org/publication/cold-start-hot-wars-indian-armys-new-limited-war-doctrine>.

9 Unnithan, Sandeep, 'We will Cross Again', India Today, 4 Jan. 2017, <https://www.indiatoday.in/magazine/interview/story/20170116-lt-general-bipin-rawat-surgical-strikes-indian-army-985527-2017-01-04>.

10 Syed, Baqir Sajjad, 'Specific proof of Indian terrorism in Pakistan unveiled', Dawn, 15 Nov. 2020, $<$ https://www.dawn.com/news/1590441>.

11 Ibid

12 Dawn, Pakistan unveils dossier on war crimes, rights violations in Indian-occupied Kashmir', 12 Sep. 2021, <https://www.dawn.com/news/1645981>.

13 Clary, Christopher and Narang, Vipin, 'India's Counterforce Temptations: Strategic Dilemmas, Doctrine, and Capabilities', International Security, vol. 43, no. 3, Winter 2018/19, pp. 7-52, <https:// direct.mit.edu/isec/article/43/3/7/12216/India-s-Counterforce-Temptations-Strategic $>$; The Times of India, 'Why Bind Ourselves to 'No First Use Policy', Says Defence Minister Parrikar on India's Nuclear Doctrine," 10 Nov. 2016, <https://timesofindia.indiatimes.com/india/Having-a-stated-nuclearpolicy-means-giving-away-strength-says-Parrikar/articleshow/55357107.cms $>$; and Remarks by Vipin Narang, 'Plenary: Beyond the Nuclear Threshold: Causes and Consequences of First Use', Carnegie International Nuclear Policy Conference, Washington, DC, 20 Mar. 2017, <https://carnegieendowment. org/2017/03/20/plenary-beyond-nuclear-threshold-causes-and-consequences-of-first-use-pub-64779>.

14 Bagchi, Indrani, 'No first use' of nukes policy is open to review: Rajnath Singh', The Times of India, 17 Aug. 2019, <timesofindia.indiatimes.com/india/no-first-use-of-nukes-policy-is-open-to-review-rajnath/articleshow/70707921.cms>.

15 Chaudhury, Dipanjan Roy, 'Why bind ourselves to 'no first use policy', says Manohar Parrikar on India's nuke doctrine', The Economic Times, 12 Jul. 2018, <https://economictimes.indiatimes.com/ news/defence/why-bind-ourselves-to-no-first-use-policy-says-parrikar-on-indias-nuke-doctrine/articleshow $/ 55357808 . \mathrm{cms}$ ?from $=\mathrm{mdr}>$. 
16 Clary, Christopher and Narang, Vipin, 'India's Counterforce Temptations: Strategic Dilemmas, Doctrine, and Capabilities', International Security, vol. 43, no. 3, Winter 2018/19, pp. 7-52, <https://direct. mit.edu/isec/article/43/3/7/12216/India-s-Counterforce-Temptations-Strategic $>$.

17 Arms Control Association, 'India's Draft Nuclear Doctrine', <https://www.armscontrol.org/act/199907/indias-draft-nuclear-doctrine>, accessed on 12 Oct. 2021.

18 Hussain, Mian Zahid and Ahmed, Raja Qaiser, 'Space Programs of India and Pakistan: Military and Strategic Installations in Outer Space and Precarious Regional Strategic Stability', Space Policy, vol. 47, Feb. 2019, pp. 63-75, <https://www.sciencedirect.com/science/article/abs/pii/S0265964617300929>.

19 Dawn, 'India revokes occupied Kashmir's special autonomy through rushed presidential decree', 5 Aug. 2019, <https://www.dawn.com/news/1498227>.

20 Resolution 47, The India-Pakistan Question, UNSCR, <http://unscr.com/en/resolutions/doc/47>.

21 International Crisis Group, 'Raising the Stakes in Jammu and Kashmir', Report No. 310, 5 Aug. 2020, <https://www.crisisgroup.org/asia/south-asia/kashmir/310-raising-stakes-jammu-and-kashmir>.

22 'Agreement on Bilateral Relations between the Government of India and the Government of Pakistan (Simla Agreement) July 2, 1972' UN Peacemakers, <https://peacemaker.un.org/sites/peacemaker. un.org/files/IN\%20PK_720702_Simla\%20Agreement.pdf $>$.

23 Saaliq, Sheikh and Hussain, Aijaz, 'India's Residency Law in Kashmir Amplifies Demographic Fears," The Washington Post, 4 Aug. 2020, <https://www.washingtonpost.com/world/asia_pacific/indias-residency-law-in-kashmir-amplifies-demographic-fears/2020/08/04/35403ed2-d6ca-11 ea-a 788-2ce86 ce81129_story.html>.

24 Malik, Mahvish, 'Nuclear Normalcy: A Reality Check of India's Nuclear Non-Proliferation Record', Strategic Studies, vol. 39, no. 2, Summer 2019, pp. 18-32, <https://www.jstor.org/stable/48544297?refreqid=excelsior $\% 3 \mathrm{~A} 7 \mathrm{~b} 7172 \mathrm{c} 3748365 \mathrm{aa} 27 \mathrm{bdb} 3268 \mathrm{~b} 84 \mathrm{a} 20 \mathrm{f} \&$ seq $=1 \#$ metadata_info_tab_contents $>$; and Mustafa, Malik Qasim; Jalili, Ghazala Yasmin; and Mahmood, Tahir, 'Pakistan and India: Non-proliferation Credentials', Islamabad Papers, Nuclear Paper Series No. 2, 2016, <http://issi.org.pk/wp-content/ uploads/2016/02/Nuclear-Paper-Series-No.-2.pdf $>$.

25 'International Panel on Fissile Materials, 'Countries: India', https://fissilematerials.org/countries/ india.html $>$, accessed on 12 Oct. 2021.

26 International Institute for Strategic Studies, 'Chapter Six: Asia', The Military Balance, vol. 121, no. 1, 24 Feb. 2021, pp. 218-313, <https://www.tandfonline.com/doi/full/10.1080/04597222.2021.1868795>.

27 India is set to acquire \$2.8 billion worth of MH-60R Seahawk helicopters, which will help the Indian Navy's prowess in the Indian Ocean against China. It has also been offered a Missile Technology Control Regime Category-1 Sea Guardian unmanned aerial system and is slated to receive 30 of them. Additionally, India acquired P8I Anti-Submarine Warfare (ASW) aircraft worth \$3 billion for the Indian Navy, 22 Anti-ship Harpoon missiles from Boeing worth \$200 million, AH-64E Apache Guardian Attack Helicopters and CH-47F Chinook helicopters worth \$5 billion and 10 C-17 Globe master III heavy-lift transport aircraft for $\$ 4$ billion. Siddiqui, Huma, 'India-US Military trade to soon touch $\$ 25 \mathrm{bn}$; and Boeing offers F-15EX Eagle for IAF', Financial Express, 29 Jan. 2021, <https://www.financialexpress. $\mathrm{com} /$ defence/india-us-military-trade-to-soon-touch-25-bn-boeing-offers-f-15ex-eagle-for-iaf/2181814>.

28 Mustafa, Malik Qasim, 'India's Offensive Military Preparedness Against Pakistan: A Threat to Regional Peace and Stability', Issue Brief, Institute of Strategic Studies Islamabad, 16 Oct. 2017, <http:// issi.org.pk/wp-content/uploads/2017/10/IB_Qasim_October_16_2017.pdf>.

29 The Indian Express, 'Army Chief Bipin Rawat Warns Pakistan: Second Surgical Strike if it is Required', 26 Sep. 2017, <https://indianexpress.com/article/india/army-chief-bipin-rawat-warns-pakistansecond-surgical-strike-if-that-is-required-4861237>.

30 Boone, Jon, 'Narendra Modi Labels Pakistan "Mothership of Terrorism”, The Guardian, 16 Oct. 2016, <https://www.theguardian.com/world/2016/oct/16/narendra-modi-mothership-of-terrorism-pakistan-brics-goa>.

31 Salik, Naeem, 'Pakistan's Nuclear Force Structure in 2025', Carnegie Endowment for International Peace, 20 Jun. 2016, <https://carnegieendowment.org/2016/06/30/pakistan-s-nuclear-force-structure-in2025-pub-63912>; and Haider, Sajjad, 'Pakistan has World's Fastest Growing Nuclear Programme: US think tank', Dawn, 24 Nov. 2014, < https://www.dawn.com/news/1146584>.

32 Ibid.

33 Khattak, Masood Ur Rehman, 'Indian Military Modernisation: Implications for Pakistan', Strategic Studies, vol. 39, no. 1 Spring 2019, pp. 20-40, <https://www.jstor.org/stable/48544286? seq=1\#metadata_info_tab_contents $>$. 
34 Ministry of Foreign Affairs, Government of Pakistan, Pakistan Nuclear Security Regime, Government of Pakistan, 2020, https://mofa.gov.pk/wp-content/uploads/2020/02/NSRFinal08-02-2020.pdf>.

35 Mirza, Adeel Mukhtar, 'Pakistan Has Contributed Significantly to the Fight Against Terrorism' The Diplomat, 8 Jan. 2021, <https://thediplomat.com/2021/01/pakistan-has-contributed-significantly-to-the-fight-against-terrorism>.

36 Ministry of Foreign Affairs, Government of Pakistan, Pakistan Nuclear Security Regime, Government of Pakistan, 2020, https://mofa.gov.pk/wp-content/uploads/2020/02/NSRFinal08-02-2020.pdf $>$.

37 Ibid.

38 Mustafa, Malik Qasim; Jalil, Ghazala Yasmin; and Azad, Tahir Mahmood, 'Pakistan's Export Control Regime', Islamabad Papers 2016, Nuclear Paper Series No 5, Institute of Strategic Studies Islamabad, <https://issi.org.pk/pakistans-export-control-regime>.

39 Mustafa, Malik Qasim; Jalili, Ghazala Yasmin; and Mahmood, Tahir, 'Pakistan and India: Non-proliferation Credentials', Islamabad Papers, Nuclear Paper Series No. 2, 2016, <http://issi.org.pk/wp-content/uploads/2016/02/Nuclear-Paper-Series-No.-2.pdf $>$.

40 For the application of peaceful nuclear technology in Pakistan, see Pakistan Atomic Energy Commission, <http://www.paec.gov.pk>.

41 Craig, Malcolm M., 'Where did the idea of an 'Islamic bomb' come from?," The Conversation, 9 Feb. 2017, <https://theconversation.com/where-did-the-idea-of-an-islamic-bomb-come-from-69385>.

42 Urban, Mark, 'Saudi nuclear weapons “on order” from Pakistan', BBC, 6 Nov. 2013, <https://www. bbc.com/news/world-middle-east-24823846>.

43 Pakistan has repeatedly denied media reports on selling nuclear technology or weapons to Saudi Arabia. Al Arabiya, 'Pakistan Denies Any Nuclear Deal with Saudi Arabia', Al Defaiya, 11 Nov. 2013, $<$ https://www.defaiya.com/news/Regional\%20News/KSA/2013/11/11/pakistan-denies-any-nuclear-deal-with-saudi-arabia>; and AFP, 'Pakistan Denies Saudi Nuclear Sale', The Express Tribune, 5 Jun. 2015, <https://tribune.com.pk/story/898183/pakistan-denies-saudi-nuclear-sale>.

44 Examples include the Indo-US nuclear deal, the Indo-US 10 Year Defence Framework Agreement, Logistics Exchange Memorandum of Agreement (LEMOA), Communications, Compatibility and Security Agreement (COMCASA), the Industrial Security Agreement (ISA) and Basic Exchange and Cooperation Agreement for Geo-Spatial Cooperation (BECA). Kullashri, Vaibhav, 'India's Defence Ties with Major Powers and Its Impact', The Kootneeti, 2 Jul. 2020, <https://thekootneeti.in/2020/07/02/indias-defence-ties-with-major-powers-and-its-impact>; and Garamone, Jim, 'U.S., India Sign 10-Year Defense Framework Agreement," US Department of Defence, 4 Jun. 2015, <https://www.defense.gov/Explore/ News/Article/Article/604775>; Indian Defence Review, 'India and the US Sign the Logistics Exchange Memorandum of Agreement (LEMOA)', 30 Aug. 2016, <http://www.indiandefencereview.com/news/ india-and-the-us-sign-the-logistics-exchange-memorandum-of-agreement-lemoa>; Pubby, Manu, 'India, US ink COMCASA deal at 2+2 Dialogue', The Economic Times, 7 Sep. 2018, $<$ https://economictimes. indiatimes.com/news/defence/comcasa-india-to-get-access-to-real-time-encrypted-information-from-us/ articleshow/65710975.cms?from=mdr>; and The Economic Times, 'Basic Exchange and Cooperation Agreement for Geo-Spatial Cooperation', 23 Oct. 2020, <https://economictimes.indiatimes.com/news/ defence/basic-exchange-and-cooperationagreement-for-geo-spatial-cooperation/articleshow/78820683. cms $>$.

45 Department of State, A Free and Open Indo-Pacific: Advancing a Shared Vision, United States of America, 4 Nov. 2019, <https://www.state.gov/wp-content/uploads/2019/11/Free-and-Open-Indo-Pacific-4Nov2019.pdf>; and Office of the Press Secretary, Remarks by President Obama to the Australian Parliament, The White House, 17 Nov. 2011, <https://obamawhitehouse.archives.gov/the-press-office/2011/11/17/remarks-president-obama-australian-parliament>.

46 Council on Foreign Relations, 'U.S.-India Relations: 1947-2020', <https://www.cfr.org/timeline/ us-india-relations>.

47 Office of the Executive Director for International Cooperation, 'US-India Defence Technology and Trade Initiative', US Department of Defense, $<$ http://www.acq.osd.mil/ic/DTTI.html >; Indian Defence Review, 'India and the US Sign the Logistics Exchange Memorandum of Agreement (LEMOA)', 30 Aug. 2016, $<\mathrm{http}: / / \mathrm{www}$.indiandefencereview.com/news/india-and-the-us-sign-the-logistics-exchangememorandum-of-agreement-lemoa $>$; Pubby, Manu, 'India, US ink COMCASA deal at 2+2 Dialogue', The Economic Times, 7 Sep. 2018, <https://economictimes.indiatimes.com/news/defence/comcasa-indiato-get-access-to-real-time-encrypted-information-from-us/articleshow/65710975.cms?from=mdr>; and The Economic Times, 'Basic Exchange and Cooperation Agreement for Geo-Spatial Cooperation', 23 
Oct. 2020, <https://economictimes.indiatimes.com/news/defence/basic-exchange-and-cooperationagreement-for-geo-spatial-cooperation/articleshow/78820683.cms>.

48 Squassoni, Sharon, 'The U.S.-Indian Deal and Its Impact', Arms Control Today, <https://www.armscontrol.org/act/2010-07/us-indian-deal-its-impact>, accessed on 12 Oct. 2021.

49 Smith, Sheila A., 'The Quad in the Indo-Pacific: What to Know', Council on Foreign Relations, 27 May 2021, <https://www.cfr.org/in-brief/quad-indo-pacific-what-know>.

50 Vaishnav, Milan, 'Religious Nationalism and India's Future', Carnegie Endowment for International Peace, 4 Apr. 2019, <https://carnegieendowment.org/2019/04/04/religious-nationalism-and-india-s-future-pub-78703>.

51 Encyclopaedia Britannica, 'Rashtriya Swayamsevak Sangh', 11 Feb. 2021, <https://www.britannica. com/topic/Rashtriya-Swayamsevak-Sangh>; and Rashtriya Swayamsevak Sangh, 'Vision and Mission', 22 Oct. 2012, <https://www.rss.org/Encyc/2012/10/22/rss-vision-and-mission.html>.

52 Naqash, Tariq, 'No military solution to Kashmir issue, says AJK president', Dawn, 14 Nov. 2018, $<$ https://www.dawn.com/news/1445471>.

53 Xinhua, 'India carries out over 3,000 ceasefire violations this year: Pakistan," 21 Dec. 2020, <http:// www.xinhuanet.com/english/2020-12/21/c_139605429.htm>; Mughal, Roshan and Ahmed, Munir, '12 killed as India, Pakistan trade fire in disputed Kashmir' Associated Press, 13 Nov. 2020, <https://apnews. com/article/pakistan-india-kashmir-ece9dd19ae41b7c6734a80d2ea6d684c>; Dawn, "Pak-India skirmish," 2 Jan. 2015, <https://www.dawn.com/news/1154533>.

54 Subedi, DB and Timilsina, Bikram, 'Most Read of 2020: Border Disputes Between India and Nepal: Will India Act as a Responsible Rising Power?', Australian Institute of International Affairs, 8 Jan. 2021, $<\mathrm{https}$ ://www.internationalaffairs.org.au/australianoutlook/20832>; The Diplomat, 'India-Sri Lanka Relations', <https://thediplomat.com/tag/india-sri-lanka-relations >; and Balazs, Daniel, 'The China-India Standoff in Ladakh: A Relook', The Diplomat, 9 Dec. 2020, <https://thediplomat.com/2020/12/the-chinaindia-standoff-in-ladakh-a-relook>.

55 PTI, 'NSA Ajit Doval's "Double Squeeze" Strategy will Never Succeed: Pakistan', The Economic Times, 13 Jul. 2018, <https://economictimes.indiatimes.com/news/defence/nsa-ajit-dovals-doublesqueeze-strategy-will-never-succeed-pakistan/articleshow/60791752.cms>.

56 Chatzky, Andrew and McBride, James, 'China's Massive Belt and Road Initiative', Council on Foreign Relations, <https://www.cfr.org/backgrounder/chinas-massive-belt-and-road-initiative>, last updated 28 Jan. 2020; and 'China's Belt and Road Initiative', Belt and Road Initiative, <https://www.beltroad-initiative.com/belt-and-road>, accessed on 12 Oct. 2021.

57 'India Rejects China's Invite to attend Belt and Road Initiative Meet for the Second Time', Business Today, 8 Apr. 2019, <https://www.businesstoday.in/latest/economy-politics/story/india-rejects-chinainvite-to-attend-belt-and-road-initiative-meet-for-the-second-time-183508-2019-04-08>; PTI, 'India refuses to endorse China's Belt and Road Initiative', The Hindu, 10 Jun. 2018, <https://www.thehindu. $\mathrm{com} /$ news/national/india-refuses-to-endorse-chinas-belt-and-road-initiative/article24128902.ece? cf chl_captcha tk_=pmd_AM6z2a5.814OJKz.MoanfZcIlHx2fhI9dCRGL0X2POc-1631679440-0-gqNtZ̄GzNAy $\bar{W}$ jenBszRmR>; and Aamir, Adnan, 'India's Opposition to CPEC on Shaky Ground', Asia Times, 1 Apr. 2020, <https://asiatimes.com/2020/04/indias-opposition-to-cpec-on-shaky-ground>.

58 Blank, Jonah, 'Regional Responses to U.S.-China Competition in the Indo-Pacific', RAND, 2021, $<$ https://www.rand.org/content/dam/rand/pubs/research_reports/RR4400/RR4412z2/RAND_RR4412z2. pdf $>$.

59 "India Begins Manufacturing 400 T-90S Tanks for Army: Report," Defence World, March 17, 2020, https://www.defenseworld.net/news/26530/India_Begins_Manufacturing_400_T_90S_Tanks_for_ Army_Report\#.YT8nPp0zaUk

60 “Pakistan Promotes 'Strategic Restraint Regime,’” NTI, August 23, 2006, https://www.nti.org/gsn/ article/pakistan-promotes-strategic-restraint-regime/ 